\title{
Hean Mining redesigned - innovation and technology needs for the future-a South African perspective
}

\author{
by M. Hermanus*
}

\begin{abstract}
Synopsis
This paper outlines global and local developments in minerals extraction of relevance to mining companies, equipment manufacturers, and state institutions, and describes a new attempt to revitalize mining in South Africa. This initiative, Operation Mining Phakisa, arises from a multistakeholder process and has the potential to provide a coherent and comprehensive response to the wide range of issues impacting the sector. The South African mining sector is in a predicament as contradictions rooted in its apartheid past have come home to roost, mineral prices remain stubbornly low, and another industrial revolution affecting all industries, including mining, gets underway.

Keywords mining, structural change, innovation, transformative technology, multistakeholder process.
\end{abstract}

commodity-intensive sectors such as public infrastructure and heavy industry giving way to 'commodity-light' investments in services and consumption. In addition, China was turning its attention to investment outside of the country to rebuild ancient trade routes across Eastern Europe and Asia, over land and sea - the so-called 'Silk Routes'. This is an ambitious plan with interrelated objectives, such as increasing the country's trade options, enabling Chinese companies to work outside of China (since demand is slow at home), and acquiring assets along the routes in exchange for infrastructure. Of themselves, the new Silk Routes are not expected to affect commodity prices, either positively or negatively (Bloomberg, 2016).

Falling demand for minerals has led to lower levels of return and reduced interest from investors and lenders, and has brought many longstanding uncertainties and externalities associated with the business of mining into the foreground and into the public eye. These include uncertainties around energy supply, the future of fossil fuels, and the availability of water; the costing of environmental and health impacts, access to mining land and land use, and the magnitude and severity of environmental and social impacts (Bardi, 2014; Thorndahl, 2011; Marinovich, 2016; Momberg and Rich, 2015; Ernest and Young, 2015).

Exploration activity has also been affected by dwindling investor interest, with greenfield exploration dropping to $29 \%$ of total exploration globally and exploration finance dropping to $9 \%$ of 2007 levels on Canadian exchanges (PDAC, 2016). While at a global level lower energy costs staved off the closure of high-cost mines, mining companies continued to experience difficulties centred on

\footnotetext{
* Natural Resources and Environment Unit of the CSIR (Council for Scientific and Industrial Research), South Africa.

(C) The Southern African Institute of Mining and Metallurgy, 2017. ISSN 2225-6253. Paper received July 2016; revised paper received Apr. 2017.
} 


\section{Mining redesigned - innovation and technology needs for the future}

the viability of current mining methods and the (high) full costs of mining operations. While 'lean and low-cost' is the desired state for many operators, there are limits to the adjustments that can be made by mining companies. In most countries minerals are national assets and mining companies are expected to contribute to economic and social development, over and above the usual benefits associated with extraction and the payment of royalties. In developing countries this includes the contribution which mining can make to industrial and social development.

Against the backdrop of global developments and trends, this paper reflects on how these issues and the attendant tensions are playing out in South Africa. A recent report by the Prospectors and Developers Association of Canada (PDAC et al., 2015, p. 1) was forthright about the future of mining, stating bluntly that 'innovation is the key to mining survival'. This is a theme that features strongly in the deliberations which are underway in South Africa about the shape and future of gold and platinum mining in particular.

\section{Why is innovation considered a necessity for mining?}

Mining companies typically adjust to lower demand and prices by delaying expenditure, cutting operational costs, and reducing output. In an environment of structural change, mining companies are at the same time challenged to assess and adjust their operations in fundamental ways.

The necessity of innovation in mining has become a refrain across the globe. Deloitte and Ernst and Young (Deloitte Touche Tohmatsu Ltd., 2015, pp. 1-3; Ernst and Young, 2015, pp. 2-3) argued in recent reports that innovation by mining companies would be an appropriate response to low commodity prices, and would better position them to weather the prolonged downturn that is expected to follow the supercycle. Both the Prospectors and Developers Association of Canada (PDAC) and Deloitte observed that while most mining companies agreed on the need to innovate, and while many were engaged in some form of innovation, innovation programmes were generally neither strategic, consistent, nor systematic. While some programmes took in novel ways to raise productivity, for example through automation, enhanced drilling or rock-breaking systems, integrated real-time data, and savings on energy costs, most were focused on optimizing existing systems.

Surprisingly, major mining companies were found on the whole to be less competent innovators than junior miners or service and supply companies (PDAC et al., 2015, pp. 2, 1011; Deloitte et al., 2016, pp. 8-13). In overview, innovation efforts were largely directed towards 'better, cheaper extraction' with smaller investments going towards innovations which are new and which bring either incremental or transformational change (PDAC et al., p. 8). Yet mining companies also acknowledged that step change was required for growth and efficiency, and that more sustainable methods of generating value were required (PDAC et al., 2015, p. 10).

Nonetheless, even under normal conditions levels of mining are not easily lowered as companies are inclined to continue to mine in order to maintain cash flow or employment levels (particularly when required to do so), to avoid penalties for reduced port or rail usage such as in
Australia, and to stave off mine closure costs. To improve their prospects, mining companies have been advised to stay close to investment initiatives in China to benefit from potential infrastructure rollouts, to develop new strategies to reduce debt and raise finance, and to anticipate that for prices to recover, the supply of minerals would have to shrink.

\section{Parallel developments transforming industry in general}

Increasing costs and pressures on the mining sector have arisen at a particularly inauspicious time, as a fourth industrial revolution gets underway. The first industrial revolution, which started in the 19th century, entailed the use fossil fuels to power machines, which stimulated steampowered mechanical production. The second, which got underway from the late 19th century onwards, was grounded in breakthroughs in electricity distribution, communication systems, and power generation, which accelerated mass production and trade. The third industrial revolution, which is still unfolding, started in the 1950s and involved the development of electronics, digital systems, computing power, and communication technology. This greatly enhanced the generation, processing, and sharing of information (World Economic Forum, 2016; UBS, 2016).

It is already apparent that next industrial era will be characterized by extreme automation and connectivity, involving cyber-physical systems that create wholly new capabilities for people and machines. Of relevance to the mining sector are the transformative technologies associated with this fourth industrial revolution and its potential to deepen inequality and reduce job security. Higher levels of unemployment and lower levels of job creation are anticipated, with many of the resulting jobs expected to require high levels of education and specialized study. In contrast, mining is expected to provide more employment and secure work, as it has done historically.

The main challenge of the fourth industrial revolution is whether it can contribute substantively to broad-based growth and income security (World Economic Forum, 2016). Developed countries with high levels of skills, established and flexible education systems, solid infrastructure, and well established legal systems stand to benefit. Developing countries in which low-skill labour is most abundant and in which the economy is dominated by agriculture, low-skill services, and small informal manufacturing businesses, are most at risk (UBS, 2016). This does not bode well for the prospects of developing countries in which unemployment and poverty is high. Globally, $1 \%$ of the population increasingly commands the greatest share of wealth $(1 / 2$ of all household wealth in 2015), and many countries, mostly developing, are already more unequal than others (World Economic Forum, 2016). Studies show that unequal societies tend to be more violent and less trustful (Wilkinson and Pickett, 2010), and mining is increasingly undertaken in these localities, with $90 \%$ of the world's major mining countries described as developing (World Bank and International Finance Corporation, 2002).

To whom and by what means the benefits of mining accrue is already a source of discontent as new-generation technological solutions become available to mining companies, and tensions between job creation and industrial 


\section{Mining redesigned - innovation and technology needs for the future}

development intensify. Thus, mining countries are in need of comprehensive, well-thought-out strategies for optimizing mining and the mining value chain for development. Mining companies obviously have a strong interest in business sustainability, and given that orebodies are geographically fixed, company-level plans and priorities are likely to correspond with country-level priorities. However, the two sets of interests are not necessarily convergent or interchangeable. This is especially so as many companies are transnationals, and investor and shareholder expectations are not ultimately subordinate to national considerations.

\section{Examples of innovation in mining}

Rio Tinto offers an example of strategic and transformational innovation amongst the major mining companies with a programmes aimed at achieving 'massive' efficiency in surface bulk mining through autonomous mining, increasing efficiency in recovery by sorting waste before it arrives at processing plants, and tunnelling to access deep orebodies faster (Rio Tinto plc and Rio Tinto Ltd., n.d., 2014). The 'Mine of the Future' and other new mining systems incorporate technologies such as driverless haul trucks, autonomous rail systems, robotic mining, and autonomous drilling systems. Mining equipment manufacturers are already employing sensors that capture data from fixed and mobile equipment to avoid downtime, optimize equipment operation (including navigation), and improve safety. Systems and technologies for managing mine tailings and treating water are also in demand, while the need for energy savings and access to power has created demand for installed power generation facilities at mines (Deloitte Touche Tohmatsu, 2015., pp. 9-13, 25).

The Deloitte report of 2015 pointed out that mining companies could make, and to a certain extent are making, use of technologies that cut across sectors, and by so doing secure the future of mining. These technologies have the potential to change the face of mining, although the initial crossover gains may be difficult to achieve. They include:

> Networks. Mines share their operational data with suppliers through sensors and onboard computers on mining equipment, with the possibility of eliminating all unplanned maintenance

> Machine learning. As autonomous machines and automation takes off, the machines will be capable of improving their performance / learning. Ultimately, mines could be fully autonomous, and controlled from a central hub in which staff are located

- 3D printing of critical parts on mine sites

- Modular equipment which can be constructed closer to site

> Genomics. Advances in this field have the potential to lead to successful bio-extraction and bio-remediation technologies

> Wearables. Personal protective equipment (PPE) with embedded sensors has the potential to track fatigue, alert people to the presence of machines, and direct mine services such as water and ventilation to specific parts of a mine

> Hybrid airships. This innovation, pioneered by Lockheed Martin (Mining.com, n.d.) and companies outside of mining such as Solarship, is aimed at overcoming the problems associated with inhospitable terrain and remote sites. It could open up new ways of transporting mining equipment

- Energy alternatives and energy-aligned work cycles to both reduce costs and increase flexibility.

Cronimet Chrome Mining SA is an example of a company experimenting with a novel photovoltaic-diesel power system (Cronimet Mining, n.d.).

\section{Beyond technology}

Improving mining operations and businesses does not depend only on technological success. Capital efficiency, an expanded approach to the business of mining, leadership, and an ability to work with and accommodate stakeholders are also important. PDAC and Deloitte describe these success factors as the ability of mining companies to successfully adopt new technology, to be responsive to the changing business environment, and to be accepted as reliable social partners.

New approaches to capital efficiency are related to technological innovation, and are reflected in considerations about power generation, water treatment, the management of tailing dams, and alternative uses of mined-out land (Deloitte Touche Tohmatsu, 2015, p. 8). Also included are novel arrangements for making full or better use of the capital tied up in heavy equipment.

Different approaches to the overall mining business model have emerged. Eurasian Minerals is an example of an exploration and mining company which secures its margin through a variety of means, by combining royalties, investments in key properties, and exploration discovery (PDAC et al., 2015, p. 5). As the mining business model evolves, regulators, which generally hold mining companies responsible for all the activities associated with the extraction cycle, are also challenged to revisit established approaches to regulating mines.

There is general recognition of the importance of the approach and outlook of the people leading or responsible for the key initiative of mining companies. They are required to respond to social and political complexities, growing concerns over inequality and marginalization, volatile business and operating environments, and to institutionalize innovation. Nonetheless it is apparent that although mining companies face many unique challenges, there are lessons to be learnt from other industries that have faced similar challenges to truly engage employees, and to realize gains available through networked assets and stakeholder engagement.

Also of strategic significance is the need to align company and stakeholder interests, and mining companies are advised to ensure that their social investments are consistent with their 'underlying and long-term needs'. Water, power, and technical training are cited as examples of needs that may be mutual and could lead to mutual benefits (Deloitte Touche Tohmatsu, 2015, pp. 16, 25, 28).

As the longer term outlook remains challenging, with exploration tailing off and traditional mining methods becoming less cost-efficient, mining companies will remain hard-pressed to ensure a pipeline of new projects, mine effectively, develop new ways of being profitable, and 


\section{Mining redesigned - innovation and technology needs for the future}

support social objectives. The PDAC report recommends that mining companies come together in a structured way to discuss, promote, and foster innovation (PDAC et al., 2015, p. 11).

Given the emphasis on transformational change for longterm success, it is possible that the mining sector will become more tiered than ever, with different needs for different classes of mining companies with different resources and capabilities.

South African mining is not immune to these trends and developments. In addition, its past and current disputes over land use, land ownership, and employment opportunities are indicative of entrenched problems. Setting worker and community engagement processes to rights and establishing respectful and mutually beneficial relationships continues to be especially challenging. These issues are explored in part in the next section of this paper.

\section{Historical context of South African mining}

The need for innovation in the mining sector present governments everywhere with significant challenges, and this is particularly evident in South Africa. While the country has a long history of mining and mining research, the sector is under pressure to adapt to new circumstances in which longstanding practices are no longer acceptable or economic.

Over the course of the 20th century, South African mining companies such as Anglo American, De Beers, Rand Mines, JCI, and Gold Fields grew to become global giants. Until well into the 1980s, these companies invested across and beyond the mining value chain. In the early years as mining grew, small engineering works and companies supplying support services were established around the gold mining industry, and local production of much of the equipment essential for deep-level mining got underway. These developments drove industrialization in South Africa (Turok, 2014; Innes, 1984). South African mining companies also supported the largest private research and development facility in the world, the Chamber of Mines Research Organisation (COMRO). COMRO was established in 1964 as the Mining Research Laboratory of the Transvaal, and was strongly supported by the gold mining sector until the mid1980s. By 1989 COMRO's budget had shrunk considerably, and by the 1990s it was no longer associated with the Chamber of Mines. The internationalization of the South African economy and the globalization of South African mining companies undid the need for close cooperation in mining $R \& D$ in South Africa (Pogue, 2006).

COMRO's programmes built on the outcomes of ad-hoc research projects that were carried out from 1908 onwards into mine ventilation control, mining-induced earth tremors, and hydropower. Over time, rockburst-related research settled on three main themes: mine layouts, support units and systems, and rockburst control (Durrheim, 2010). A mechanization programme was formally initiated in 1974 and from the outset involved equipment manufacturers (Pogue and Rampa, 2006). The programme involved improving efficiencies in gold mining and focused on a suite of hydraulic technologies which included hydraulic drilling and hydraulic power systems. The ultimate aim was to establish a viable mining equipment industry that could serve South
African mines. However, funding dried up before these technologies were proven.

In the final instance, the sector remained dependent on cheap labour, secured from migrant workers, and coal-based energy. But in post-apartheid South Africa, political conditions and economic conditions changed and these underpinnings have fallen away.

In the deracializing economy of today, labour is no longer as cheap as it was in the apartheid years, and the legal framework which made it possible to treat black workers as disposable no longer exists. The degrading conditions in which mineworkers laboured in South Africa and the general system which denied the humanity and dignity of black South Africans are well documented by historians, sociologists, and others (Wilson, 1972; Bundy, 1988; Innes, 1984; Platsky and Walker, 1985; Flynn, 1992; McCulloch, 2013).

In addition, energy costs are high and rising. The reasons for the relatively high cost of energy in South Africa are complex and the impacts on mining are related to the peculiarities of deep-level mining, which requires large power inputs. Coal-based power accounts for $90 \%$ of electricity supply, and the rising cost of power runs contrary to the decline in the price of coal in the global market. Rising electricity costs are due to Eskom's (the local state-owned power utility) requirements to fund new generation capacity as well as maintain its existing and ageing power stations. These costs were estimated at R340 billion in 2013, excluding borrowing costs (TIPS and Global Green Institute, 2014, p. 7). The decline of the South African currency also affected the cost of power through the cost of borrowing and the translation of coal prices into the local currency. All of these factors pointed to the likelihood of above-inflation increases for many years into the future. Based on 2009 average standard prices, the price of electricity was due to triple in 2017, affecting the operations of underground mines in particular. At this time electricity costs were expected to amount to $17 \%$ and $23 \%$ of the total costs for the extraction platinum group metals and gold respectively (Baxter, 2015). The refrigeration plants and ventilation systems required to enable work in deep mines account for a substantial portion of the power needs in these operations.

The South African mining sector has shrunk in size and value, in the face of decisions made by mining companies and developments in the local and global environment, (PWC, 2015 , p. 9). During the 1990s, when the country opened up to the global economy, key mining companies listed outside of the country unbundled their investments in the mining and industrial sectors and spent less on research and development $(R \& D)$. Since then, many mining assets have not been managed with an eye to development. Policies to empower previously disadvantaged individuals and change the ownership structure of the sector took priority from 2000 onwards. Since many empowerment deals were highly leveraged, benefits to local communities or for community development were limited, and little impact has been made on the legacy of the apartheid labour market. To compound matters, the minerals and energy complex, which is the historical backbone of the South African economy and which enabled industrialization, was systematically dismantled in the period 1994 to 2015 as efforts shifted towards building a knowledge economy (Blankley and Booysens, 2010). 


\section{Mining redesigned - innovation and technology needs for the future}

The minerals and energy complex of South Africa has been held up as an example of how mining escaped being an enclave activity (Kaplan, 2011). On the other hand, low levels of beneficiation of South Africa's primary mineral products such as gold, diamonds, chrome, platinum, and copper are considered, in contrast, as evidence of the enclave character of the mining sector (Turok, 2013).

Notwithstanding these debates, the complex's development remains an artefact of its time, of mining conditions which needed unique technology and organisation, and of a system of racial exploitation which made such mining economically viable.

The developments and priorities of the last few decades resulted in local technology and industrialization taking a back seat in South Africa. Given the particular characteristics of the country's gold and platinum deposits, $R \& D$ was (and remains) essential to developing and maintaining viable means of extraction. In coal mining, in contrast to gold and platinum mining, the main $R \& D$ challenges centred on adapting coal mining equipment to the task of cutting hard and siliceous coal seams. This challenge was solved for existing coalfields, but as coal mining is expected to continue on a large scale in at least the medium term, extraction in the north-lying coalfields could present new $R \& D$ challenges. $R \& D$ is also required to ensure that mining breaks with the past and brings broad benefits to society.

\section{Current context of South African mining}

Given the importance of moving away from coercive labour practices that were the norm under apartheid, the absence of cheap labour, cheap energy, and easily accessed orebodies, as well as falling commodity prices, South African mining companies have been searching for a fresh approach. The initial response of gold and platinum miners was to reduce the costs of operations by lowering levels of production and employment. But even as mine shafts closed rather than opened, the idea that automation could revive the growth of the sector and secure its future gained currency. However, this idea, if pursued in isolation from other interventions in the wider economy, has the potential to fly in the face of needs for job creation and decent work.

Furthermore, the significance of the place of mining in the South African economy leaves little room for complacency about the sector's waning fortunes. In 2013 it was estimated that $60 \%$ of all export revenue stemmed from the export of minerals and metals. This figure belies the size of mining's contribution to the gross value added by all sectors in the South African economy, which has shrunk, from a high of $21 \%$ in 1980 when the gold price peaked (Kantor, 2013) to 8\% in 2015 (Statistics South Africa, 2016). Mining remains an important employer in the country and accounts for significant investments in infrastructure. In the gold sector alone, in 2015, R23.4 billion was spent on the remuneration of approximately 120000 employees, and R9.4 billion was spent on capital infrastructure. Yet over the preceding decade, the rate of gold production in South Africa declined more rapidly than that of other top 10 producers, at $-7.7 \%$ per annum. Over the same period, employment declined by $4.4 \%$ per annum. Although wages increased on an average of $11 \%$ per annum, these increases have made no impact on the apartheid era wage gap. Rising electricity prices also contributed to the rapid downscaling of the gold sector. Without systemic changes in gold mining methods, the sector is expected to continue to shrink so that by 2025 production is expected to have halved relative to 2015 levels, and employment levels are expected to have declined to $43 \%$ of 2015 levels, or 68000 employees (This is Gold, 2015, pp. 2-4).

\section{Operation Mining Phakisa}

The crisis in mining was recently addressed through a multistakeholder process, Operation Mining Phakisa. The Phakisa got underway in August 2015, under the leadership of the Department of Planning, Monitoring and Evaluation (DPME), which is situated in the Presidency. It was aimed at identifying and acting on key 'constraints to investment in and growth of the sector' (Brand South Africa, 2015). The Phakisa produced a strategy and concrete plans, all dependent on the collaborative input and efforts of the key stakeholders clustered around mining. The stakeholders involved included government departments such as the Department of Performance Monitoring and Evaluation (DPME), the Department of Mineral Resources (DMR), the Department of Trade and Industry (DTI ), the Department of Science and Technology (DST) the Department of Water and Sanitation (DWS), the Department of Environmental Affairs (DEA), the Chamber of Mines (COM), the South African Mining Development Association (SAMDA), representatives of major mining companies, the National Union of Mineworkers (NUM), the Solidarity and UASA trade union, Bench Marks Foundation (an NGO), and universities such as the University of the Witwatersrand, and University of Pretoria. The Phakisa started with individual and group consultations with stakeholders, which laid the groundwork for a five-week 'laboratory' at which specific plans were developed. These consultations were conducted by staff of the DPME. Although efforts were made to create an inclusive process, the Association of Mineworkers and Construction Union (AMCU) was conspicuously absent from the Phakisa, the DMR played a notably low key role, and SAMDA representatives were dissatisfied with the level of priority (too low from their perspective) attached to the mine ownership aspects of transformation.

In overview, this DPME-led process set its sights on rebuilding the mining sector through technological excellence, social inclusion, and job creation. Stakeholders agreed that the problems in the mining sector were deeprooted and structural, tending towards self-reinforcement. The outcomes of the process required cooperation and commitment from each of the major stakeholders, and had to be viable in both financial and practical terms. Plans were developed to support investment in mining and to build local expertise in mechanized mining methods, the manufacture of mining equipment, and provision of mining-related services. Solutions to the problems experienced by communities affected by mining and associated with degraded mining land were also discussed. This discussion could pave the way for $R \& D$ aimed at addressing social needs and linking industry and society. All plans at the Phakisa were developed and 


\section{Mining redesigned - innovation and technology needs for the future}

priced collaboratively, and implementation was made conditional on securing sufficient commitment from each of the stakeholders. This included co-funding and other arrangements which lock the private and public sector into partnerships. If it was clear that these criteria could not be met, the initiative under consideration was abandoned.

The plans developed at the Phakisa, were not entirely new. They were informed in part by other developments and plans that preceded the Phakisa, such the papers and engagement that led to the promulgation of the Mineral Resources and Petroleum Development Act, the country's National Development Plan, the Mining Charter, and the work of the Mining Growth Development and Employment Task Team.

The outcomes of the Mining Phakisa ultimately took forward calls for a coherent and coordinated approach by government, with the support of the private sector, to build a 'joined-up economy'. This approach requires the extraction of (finite) mineral resources to be closely associated with concurrent initiatives to increase levels of industrialization and human capital development (Turok, 2014), and could provide the means for African countries to foster commodityled industrialization (Lopes, 2015).

Many agreements were reached at the Phakisa. For example, it was agreed that the effects of the downturn on mineworkers and their dependents amounted to a crisis requiring immediate attention. To this end a national initiative led by the Commission for Conciliation, Mediation and Arbitration (CCMA) was proposed and accepted. Longand short-term measures were devised to stimulate investment in mining and activate the mining and industrial value chain associated with mining. These included fostering inclusive participation in the mining sector by increasing the number of emerging miners, transforming the racial structure of the economy, developing new mining methods, addressing the energy crisis in mining, and targeting specific beneficiation opportunities. Plans were also developed to address the negative legacies of mining. Lastly, it was acknowledged that the dysfunctional relationships between the state and the mining sector, and between organized labour and the mining sector, needed to be set right. These relationships were to be reconfigured through the process of implementing plans conceived collaboratively.

'The broad aim ... is to galvanise growth, transformation, investment and employment creation along the entire mining value chain, in relevant input sectors and in mining related communities.'

\section{Mining equipment - implications and opportunities}

In light of these developments, the South African mining industry is now challenged to adopt appropriate technologies while supporting the development of national manufacturing capabilities i.e. the sector must be 'properly industrialized'.

This work stream of the Phakisa builds on several current and earlier initiatives and programmes such as the Industrial Policy Action Plan (IPAP) of the DTI, which focuses on specific economic sectors and employment, the Mining Charter of the DMR, which focuses on issues of ownership and socio-economic development, as well as the $R \& D$ strategy developed by the DST, and a wide-ranging strategy on sustainable growth and meaningful transformation developed in a tripartite forum, the Mining Industry Growth and Development Task Team, which was established by the DMR in 2008.

The main aspects of IPAP that are relevant to mining are located in the mineral beneficiation section, which aims to increase local inputs in the mining value chain both upstream and downstream by focusing on capital goods, consumables, and services. Four key value chains were analysed by the DTI, namely ferrous metals, polymers, titanium, and platinum group metals (Department of Trade and Industry, 2014, pp. 82-83).

The current Mining Charter contains a number of provisions of relevance to development and industrialization. It sets ownership, economic interest, and management control of mining entities by 'black economic empowerment' (BEE) groups and individuals at 26\%, the procurement of capital goods from BEE companies at $40 \%$, and the contributions by multinational suppliers to socio-economic development of local mining communities at $0.05 \%$ of the annual income of local mining companies. The Charter has been under review for some time, and key issues in the recently released revised draft charter include the retention of BEE ownership at $26 \%$ and 'equitable' distribution of these stakes among workers, black entrepreneurs, and communities; an offset of up to $11 \%$ of BEE requirements against beneficiation; an increased level (60\%) for local procurement of capital goods from BEE companies; and increased levels (>60\%) of procurement for consumable and services from local BEE companies (South Africa, 2016). The Charter review process is unfolding in parallel to developments arising from the Phakisa, and while there are opportunities for synergy, there are also points of difference that are still to be settled.

The following elements of the Phakisa process are central to reviving mining and pertinent to the interest of government, mining companies, and equipment suppliers.

> Advancing $R \& D$ pertaining to fuel cell development to reduce reliance on coal and diesel, and to leverage off the country's abundant platinum deposits

> Developing new systems of mining for narrow tabular seams. This involves mechanization and automation drawing on new developments in interconnectivity and autonomous processes

> Increasing emphasis on local manufacture of capital equipment and local ownership of manufacturing companies

> New technology for addressing the environment impacts of mining, and repurposing of mining land to new ends such as energy and clean water production, biomass production and agriculture, including new technology for the beneficiation of mining waste

- Targeted beneficiation of specific minerals such as iron ore (steel), platinum, manganese, and titanium

> Incubation of beneficiation industries

> Local skills and business development

> Self-generation of energy at mine sites

> Renewed commitments to supporting exploration.

As is evident from the above list, these initiatives are not unrelated to global developments in mining technology, but the emphasis is on localization. The Council for Industrial 


\section{Mining redesigned - innovation and technology needs for the future}

and Scientific Research (CSIR) was tasked with hosting a hub or mining-related $R \& D$ in support of the technical $R \& D$ aspects of the outcomes of the Mining Phakisa. The roles of the CSIR include managing the hub facility, which it owns; facilitating and managing tenancy by stakeholders from government, industry, the science councils, universities, and professional bodies; facilitating the development of appropriate pilot facilities at the site under the guidance of a public-private sector steering committee; and participating in or contributing to $R \& D$ projects to the extent that relevant competencies are available in the organization. The other aspects of the mining value chain are already served by dedicated institutions such as the Council for Geoscience, which focuses on exploration and matters related to Earth science, and Mintek, which focuses on the beneficiation of mineral resources. The University of the Witwatersrand and the University of Pretoria, which are home to schools of mining engineering, are expected to play a direct role in the development of mining technology, while the activities of many other universities are central to solving problems in mineral beneficiation, treating minewater, addressing environmental impacts, and providing energy solutions. At present, funding available for geoscience and mineral beneficiation $R \& D$ far outstrips that available for the mining (extraction) process itself, hence the Phakisa focus of this aspect of the minerals value chain.

The CSIR's immediate R\&D tasks are to:

> Identify and initiate mechanization solutions for South African mines which support local manufacture and solve problems related to cutting hard rock

> Install and test sensor systems for environmental monitoring in mines

> Investigate non-explosive rock-breaking methodology

> Contribute to the development of a framework and decision support system for real-time monitoring technology to support personnel-machine interactions, machine-rock interactions, and machine-to-machine communication

> Contribute to the development of mining layouts and support systems to provide for mechanized mining

- Understand the role of rock engineering in mechanized mining in South Africa.

These tasks are to be accomplished through collaboration with other research institutions, mining companies, and manufacturers in the country.

Since the conclusion of the Mining Phakisa, work has started on establishing the 'Mining Hub'. In essence, the need for a strong collaborative centre for mining-related research is in the process of being re-established, with government committed to partnering with industry. The DST committed seed money towards its establishment and further funds have been secured through interactions with Treasury. Plans to bring equipment suppliers and mining companies into the hub have already been successfully implemented. The DTI's substantial role in the hub is informed by its Resources Capital Goods Development Programme (Davies, 2015). These first steps to address the technology needs of South African mines, and the process envisaged, should ensure that the appropriate technologies are developed and that impetus is given to the development of local industry.
However, the hurdles inherent in developing mechanization and automation processes for the South African mining sector are still to be overcome. These are significant. Identifying and mechanizing those parts of the mining process which would immediately benefit from mechanization is the first challenge, and thereafter lies a meticulous phase of revisiting the extraction process in its entirety to properly understand the conditions, processes, equipment, and skills requirements for automation. This all before automation can be realized, and most likely not for all mines. Since this is a long and painstaking pathway it provides stakeholders, if they remain committed, with the time to build deep consensus on the way forward, and properly plan for the scale and impact of the changes to come.

\section{Conclusions}

The operational and business models of mining are being revisited across the world and in South Africa. The private sector (mining companies and investors) has to reconceptualize how mining can be undertaken profitably and to the benefit of society, both locally and at large.

In South Africa, a coordinated technical innovation programme has been initiated as part of a larger plan which also addresses the social and environmental legacies of mining and spearheads reindustrialization. The ingredients for success, namely co-funding, public-private partnerships, linking $R \& D$ to industry, and social needs and co-planning are all present.

Building local expertise, manufacturing capability, and skills development are central to this endeavour, but the challenges that lie ahead are immense. Most significant are the difficulties of transferring tasks currently performed by mineworkers to machines while concurrently creating manufacturing and other jobs opportunities. Implicit is the need to revisit and redesign mining processes to support automation and to create development opportunities in the wider economy.

The mining Phakisa has opened up many opportunities for the private sector, especially for equipment manufacturers. Under enabling conditions the response of the private sector to the call to innovate will determine whether these opportunities can be realized. For many companies in the mining, industrial, and financial sectors, the emphasis on localization may present fundamental shifts in business strategy.

\section{References}

BARDI, H. 2014. Extracted. How the Quest for Mineral Wealth is Plundering the Planet. Chelse Green Publishing.

BAXTER, R. 2015. The future of the South African Mining industry. Chamber of Mines of South Africa, Johannesburg.

BLANKLEY, W.O. and Booysens, I. 2010. Building a knowledge economy in South Africa. South African Journal of Science, vol. 106, no. 11/12. pp. 1-6.

BLOOMBERG. 2016. Commodities crash boosts China's new Silk Road. http:// http://www.hellenicshippingnews.com/commodities-crash-boosts-chinasnew-silk-road/ 


\section{Mining redesigned - innovation and technology needs for the future}

BRAND SOUTH AFricA. 2015. Mining operation phakisa gets going. https://www.brandsouthafrica.com/investmentsimmigration/business/economy/development/phakisa-mining-150515

Bundy, C. 1988. The Rise and Fall of the South African Peasantry. 2nd edn. David Philip. Cape Town.

CRonimet Mining. Not dated. Cronimet mining energy. http://www.cronimet-mining.com/en/energy

DAVIES, R. 2015. Mining still a key pillar for SA economy. http:// allafrica.com/stories/201502091736.html

Deloitte Touche Tohmatsu Ltd. 2015. Tracking the trends 2016. The 10 top issues mining companies will face in the coming year. https://www2.deloitte.com/content/dam/Deloitte/global/Documents/Energ $\mathrm{y}$-and-Resources/gx-er-tracking-the-trends-2016.pdf

Deloitte, Monitor, Doblin, Investing In African Mining IndabA, and Chamber of MinEs. 2016. Innovation State of Play. Africa. Mining Edition 2016. http://www.polity.org.za/article/innovation-state-of-play-africa-miningedition-2016-feb-2016-2016-02-09

Department of TRAde And Industry. 2014. Industrial policy action plan 2016/17. Economic sectors and Employment Cluster. IPAP 2014/15-2016/7. Pretoria.

DuRrHEIM, R.J. 2010. Mitigating the risk of rockbursts in the deep hard rock mines of South Africa: 100 years of research. Extracting the Science: A Century of Mining Research. Brune, J. (ed.). Society for Mining, Metallurgy and Exploration, Littleton, CO. pp. 156-171. http://africaarray.psu.edu/publications/pdfs/SME100_Durrheim_Rockburs t\%20research.pdf

ERNEST AND Young. 2015. Business risks facing mining and metals 2015-2016. http://www.ey.com/gl/en/industries/mining---metals/business-risks-inmining-and-metals-old-2

FlynN, L. 1992. Studded with Diamonds and Paved with Gold. Miners, Mining Companies and Human Rights in Southern Africa. 1st edn. Bloomsbury, London.

InNES, D. 1984. Anglo. Anglo American and the Rise of Modern South Africa. Ravan Press, Johannesburg.

KanToR, B. 2013. How important is mining in the SA economy? It depends on how you measure it. http://www.zaeconomist.com/sa-economy/howimportant-is-mining-to-the-sa-economy-it-depends-on-how-youmeasure-it/

KAPLAN, D. 2011. South African mining equipment and related services: growth constraints and policy. MMCP Discussion Paper no. 5. http://www.prism.uct.ac.za/papers/mmcp\%20paper\%205_0.pdf

LOPES, C. 2015. Is the commodities super cycle slowdown a shock for Africa?. https://www.uneca.org/es-blog/commodities-super-cycle-slowdownshock-africa [Accessed 16 April 2016]

Marinovich, G. 2016. Murder at Small Koppie. The real story of the Marikana massacre. Penguin Random House South Africa, Cape Town

McCulloch, J. 2013. South Africa's Gold Mines and the Politics of Silicosis. Jacana Press, Johannesburg.

Mining.com. Not dated. Breakthrough aircraft to tranform remote mining http://www.mining.com/breakthrough-aircraft-to-transform-miningeconomics

MomberG, J. and Rich, E. 2015. Beyond Governments: Making Collective Governance Work. Lessons from the Extractive Industries Initiative (ETI). Greenleaf Publishing.

PDAC, Monitor, Doblin, Deloitte. 2015. Innovation state of play. Mining edition 2015.

https://www2.deloitte.com/content/dam/Deloitte/br/Documents/energyresources/Innovation_State_of_Play.PDF

PDAC. 2016. PDAC briefing note. A capital opportunity: responding to the prolonged downturn in mineral exploration financing. http://www.pdac.ca/docs/default-source/public-affairs/budget-2016-pdacrecommendation---metc.pdf?sfvrsn=2

Platsky, L. and Walker, C. 1985. The Surplus People. Forced Removals in South Africa. 1st edn. Ravan Press, Johannesburg.
Pogue, E. 2006. Missed opportunities? A case study from South Africa's mining sector. Resource Intensity, Knowledge and Development Insights from Africa and South America. Lorentzen, J. (ed.). HSRC Press, Cape Town. Chapter 5, pages 179-213.

http://www.ieri.org.za/sites/default/files/outputs/Resource_Intensity_Chap ter_5_mining_sector.pdf

Pogue, E. and Rampa, M. 2006. Innovation in resource-based technology clusters. Investigating the lateral migration thesis. Human Sciences Research Council, Pretoria.

PWC. 2015. SA Mine, 7th edn. Highlighting trends in the South African mining industry. https://www.pwc.co.za/en/assets/pdf/sa-mine-2015.pdf

Rio TinTo PLC and Rio TinTo LTD. Not dated. Technology and innovation. http://www.riotinto.com/technology-and-innovation-160.aspx

Rio Tinto plc and Rio Tinto Ltd. 2014. Mine of the Future. Next generation mining: people and technology working together. https://www.youtube.com/watch?v=91_EbGLItyY

THIS IS GoLD. 2015. SA gold, today and tomorrow fact sheet 2015 http://www.thisisgold.co.za/downloads/finish/4-fact-sheets/59-southafrican-gold-today-and-tomorrow

SchussLer, M. 2016. The depressive super cycle. https://www.moneyweb.co.za/moneyweb-opinion/the-depressive-supercycle/ [Accessed 30 May 2016].

South Africa. 2016. Reviewed Broad Based Black Economic Empowerment Charter for the South African Mining and Minerals Industry, 2016. Government Gazette, vol. 610, no. 39933, 15 April 2016.

Statistics South Africa. 2016. Gross Domestic Product, 4th Quarter 2016. http://www.statssa.gov.za/publications/P0441/GDP_presentationQ4_2016.pdf [Accessed 30 March 2017].

THoRndAHL, M. 2011. International Development Policy: Energy and Development. Graduate Institute of International and Development Studies, Geneva.

TIPS and Global GreEn Institute. 2014. The impact of electricity price increases on the competitiveness of selected mining sector and smelting value chains in South Africa. https://www.tips.org.za/researcharchive/sustainable-growth/green-economy3/item/download/912_d664ce65069c5a9fof699a4121604fa9

TuRoK, В. 2013. Problems in the mining industry in South Africa. http://ecdpm.org/great-insights/growth-to-transformation-role-extractivesector/problems-mining-industry-south-africa/

TuRok, B. 2014. The scope for domestic value addition in a mining economy the South African case. New Agenda. https://ifaacapetown.files.wordpress.com/2015/02/prof-turok.pdf

UBS. 2016. Extreme automation and connectivity: the global, regional, and investment implications of the fourth industrial revolution. https://www.ubs.com/global/en/about_ubs/follow_ubs/highlights/davos2016.html

WiLkinson, R. and PickEtT, K. 2010. The Spirit Level: Why Equality is Better for Everyone. Penguin.

WiLson, F. 1972. Labour in the South African Gold Mines 1911-1969. Cambridge University Press, Cambridge, UK.

WorLd BANK GRoup. 2016. Commodity Markets Outlook. Weak growth in emerging economies and commodity markets. January. https://openknowledge.worldbank.org/handle/10986/23680

World Bank and International Finance Corporation. 2002. Mining and Development. Treasure or trouble. Mining in developing countries. http://siteresources.worldbank.org/INTOGMC/Resources/ treasureortrouble.pdf

WorLd ECONomic Forum. 2016. What is the Fourth Industrial Revolution? https://www.weforum.org/agenda/2016/01/what-is-the-fourth-industrialrevolution/ 